MaPan :JurnalMatematikadanPembelajaran

p-ISSN: 2354-6883 ; e-ISSN: 2581-172X

Volume 6, No 2, December 2018 (161-172)

DOI: https://doi.org/10.24252/mapan.2018v6n2a3

\title{
MEMBANGUN KARAKTER MAHASISWA MELALUI NILAI-NILAI MATEMATIKA
}

\author{
Hamdan Sugilar1), Rahayu Kariadinata2), Ehda Farlina3), Heri Gunawan') \\ 1,2,3,4UIN Sunan Gunung Djati Bandung \\ 1,2,3,4Jalan A.H. Nasution No.105 Cibiru Kota Bandung, \\ Email: hamdansugilar@uinsgd.ac.id ${ }^{1}$, , rahayu.kariadinata@uinsgd.ac.id ${ }^{2}$, \\ ehda.farlina@uinsgd.ac.id ${ }^{3}$ ), herigunawan@uinsgd.ac.id4)
}

Submitted: 31-01-2018, Revised: 30-05-2018, Accepted: 02-07-2018

\begin{abstract}
Abstrak:
Tujuan penelitian ini adalah untuk membangun karakter mahasiswa melalui nilainilai matematika, capaian pembelajaran mata kuliah dan upayanya. Penelitian ini merupakan penelitian deskriptif kualitatif dengan pengumpulan data melalui angket, studi literatur, dan wawancara. Hasil penelitian diperoleh bahwa terdapat nilai-nilai matematika yang dapat membentuk karakter. Nilai-nilai matematika yang ada pada setiap mata kuliah dapat membangun karakter mahasiswa yang meliputi sikap sungguh-sungguh, teliti, jujur, kerja keras, tekun dan yang lainnya. Pendidikan karakter dibutuhkan oleh mahasiswa dan membutuhkan figur teladan dan bimbingan dalam membangun karakter mahasiswa.
\end{abstract}

Kata Kunci: Karakter, Nilai-Nilai Matematika

\section{BUILDING THE STUDENTS' CHARACTERS THROUGH THE MATHEMATIC VALUES}

\begin{abstract}
:
The study aims to build the students' characters through the values of mathematics, the achievement of learning subjects and efforts. The method used was qualitative method by collecting data through questionnaire, literature study, and interview. The study findings showed that there were mathematical values that were able to build the characters, the study program set the learning outcomes actualized in every subject. The values of every subject could build the students' characters through the characteristics of the subject consisting of the attitude of earnest, thorough, honest, hard work, diligent and so forth. The character education is urgently needed by the students and requires an exemplary figure and guidance in building the characters of the lecturers.
\end{abstract}

Keywords: Character, Mathematical Values

How to Cite: Sugilar, H., Kariadinata, R., Farlina, E., \& Gunawan, H. (2018). Membangun Karakter Mahasiswa melalui Nilai-Nilai Matematika. MaPan : Jurnal Matematika dan Pembelajaran, 6(2), 161-172. 
$\mathrm{P}$ endidikan karakter di perguruan tinggi bertujuan untuk meningkatkan mutu penyelenggaraan dan hasil pendidikan yang mengarah pada pencapaian pembentukan karakter dan akhlak mulia peserta didik secara utuh, terpadu, dan seimbang, sesuai standar kompetensi lulusan (Hasanah, 2013). Dalam hal ini, pendidikan karakter hendaknya dirumuskan dalam kurikulum, diterapkan metode pendidikan, dan dipraktekkan dalam pembelajaran. Inti kegiatan di perguruan tinggi dituangkan pada Tridharma Perguruan Tinggi, sehingga semua kegiatan pendidikan, penelitian, dan pengabdian kepada masyarakat dilaksanakan dengan berkarakter (Farida, 2012). Salah satu masalah karakter tidak hanya pada jenjang pendidikan menengah bahkan pendidikan tinggi pun menjadi sorotan publik misalnya: narkoba, prostitusi, miras, tawuran, rendahnya jiwa nasionalisme dan lain sebagainya. Rendahnya karakter mahasiswa dalam lingkungan kampus pun sering kali terjadi misalnya mencontek, malas kuliah, malas mengerjakan tugas, drop out, sikap acuh tak acuh terhadap dosen. Masalah karakter perlu mendapatkan perhatian yang serius khususnya dikalangan anak muda, bahwa setiap aspek masyarakat kita telah mengalami krisis Karakter hal ini terjadi dikalangan anak muda (McDonnell, 2008).

Dari berbagai fenomena tersebut pemerintah melalui peraturan presiden mengeluarkan regulasi peraturan presiden nomor 87 tahun 2017 pasal 3 tentang penguatan pendidikan karakter dilaksanakan dengan menerapkan nilai-nilai Pancasila dalam pendidikan karakter terutama meliputi nilai-nilai religius, jujur, toleran, disiplin, bekerja keras, kreatit mandiri, demokratis, rasa ingin tahu, semangat kebangsaan, cinta tanah air, menghargai prestasi, komunikatif, cinta damai, gemar membaca, peduli lingkungan, peduli sosial, dan bertanggungiawab (Republik Indonesia, 2017). Melalui pengajaran dan pembelajaran matematika, secara implisit atau eksplisit, dapat dikembangkan Berbagai karakteristik positif, seperti kemampuan berpikir kritis, kemampuan berpikir logis, analitis, kemampuan berpikir, atau teliti (Mahmudi, 2011). Pendidikan karakter mutlak diperlukan karena ada pengaruhnya pada masyarakat untuk menahan pengaruh negatif dari luar sebagai kontrol dan bimbingan kepada dirinya (Gray, 2009).

Nilai-nilai karakter yang diterapkan di perguruan tinggi adalah memilih nilai-nilai inti yang dikembangkan dalam implementasi pendidikan karakter, khususnya pada masing-masing jurusan/program studi (Hasanah, 2013). Untuk mewujudkan Perpres tentang penguatan pendidikan karakter harus melalui perencanaan, pelaksanaan, dan evaluasi yang baik dan 
berkesinambungan sehingga tidak hanya sekedar ingat dan memahami tentang Perpres namun lebih dari ini berupaya mewujudkannya.

Peraturan Presiden No 8 Tahun 2012 Tentang Kerangka Kualifikasi Nasional Indonesia (KKNI) Bab I ketentuan Umum Pasal 1 ayat (2) tentang capaian pembelajaran atau learning outcome adalah kemampuan yang diperoleh melalui internalisasi pengetahuan, sikap, keterampilan, kompetensi, dan akumulasi pengalaman kerja. Ini merupakan landasan perguruan tinggi untuk membangun kompetensi mahasiswa kedalam empat komponen. Capaian Pembelajaran menurut Permenristekdikti Nomor 44 Tahun 2015 tentang Standar Nasional Pendidikan Tinggi terdiri atas: pengetahuan, sikap, keterampilan umum dan keterampilan khusus yang saling terkait tidak dapat dipisahkan. Mahasiswa bagian dari pilar penjaga nilai-nilai karakter bangsa sekaligus juga sebagai agen perubahan tentunya harus senantiasa peka, peduli dan menjadi bagian dari membangun karakter bangsa yang baik.

Learning outcomes atau capaian pembelajaran prodi S1 pendidikan matematika bidang pengetahuan KP2 yaitu menguasai konsep teoretis matematika meliputi logika matematika, matematika diskrit, aljabar, analisis, geometri, teori peluang dan statistika, prinsip-prinsip pemodelan matematika, program linear, persamaan diferensial, dan metode numerik yang mendukung pembelajaran matematika di pendidikan dasar dan menengah serta untuk studi lanjut (Matematika, 2016). Konsep teoretis pada mata kuliah bidang kematematikaan tersebut selain berperan dalam peningkatan kompetensi pengetahuan yang utama sebesar $40 \%$ s.d. $80 \%$ kompetensi sarjana pendidikan matematika. Selain kompetensi pengetahuan yang harus dikuasi, implementasi sistem pendidikan nasional dan sistem pelatihan kerja yang dilakukan di Indonesia pada setiap level kualifikasi juga mencakup proses yang menumbuhkembangkan afeksi. Beberapa afeksi sebagai learning outcomes diantaranya: bertaqwa kepada Tuhan Yang Maha Esa; memiliki moral, etika dan kepribadian yang baik didalam menyelesaikan tugasnya, dan mampu bekerja sama dan memiliki kepekaan sosial dan kepedulian yang tinggi terhadap masyarakat dan lingkungannya. Sehingga berbeda dari penelitian lainnya, fokus penelitian ini adalah menganalisa nilai-nilai karakter yang dibangun dari matematika, bagaimana peran nilai-nilai karakter dalam membangun kompetensi learning outcomes dan bagaimana sikap mahasiswa terhadap pendidikan karakter. 


\section{METODE PENELITIAN}

Penelitian ini menggunakan pendekatan atau metode deskriptif kualitatif. Penelitian deskriptif mendefinisikan suatu keadaan atau fenomena secara apa adanya. Penelitian diadakan di Universitas Islam Negeri Sunan Gunung Djati Bandung Fakultas Tarbiyah dan Keguruan Program Studi Pendidikan Matematika. Sampel penelitian adalah mahasiswa semester ganjil tingkat tiga. Pengambilan sampel menggunakan teknik purposive sampling (sampel berdasarkan tujuan).

Instrumen yang digunakan berupa angket, pedoman wawancara dan studi literatur. Adapun analisis data yang dilakukan diantaranya, menyebarkan angket, melakukan wawancara, dan mencari literatur yang berhubungan dengan penelitian. Setelah hal tersebut dilakukan, maka langkah selanjutnya menganalisis data yang sudah diperoleh, kemudian membuat kesimpulan.

\section{HASIL PENELITIAN DAN PEMBAHASAN}

\section{Capaian Pembelajaran dalam Membangun Karakter Mahasiswa}

Nilai-nilai karakter yang diterapkan di perguruan tinggi, khususnya di LPTK sebagai penghasil guru, hanya memilih nilai-nilai inti (core volues) yang akan dikembangkan dalam implementasi pendidikan karakter, khususnya pada masing-masing jurusan/program studi. Keempat nilai-nilai karakter inti tersebut, yakni jujur, cerdas, peduli dan tangguh menjadi dasar implementasi nilai-nilai karakter (Hasanah, 2013). Pengertian karakter banyak dikaitkan dengan pengertian budi pekerti, akhlak mulia, moral, dan bahkan dikaitkan dengan kecerdasan ganda. Dalam perspektif Islam, Pendidikan Karakter merupakan upaya untuk mengembangkan keseluruhan aspek kemanusiaan manusia dalam dimensi fisik jasmani, emosi, spiritual dan intelektual, untuk menghasilkan pribadi yang memiliki karakter beriman, bertanggungjawab, peduli, jujur, berani dan menjadi warga negara yang baik (Hasanah, 2014). Karakter bukan terbentuk dengan sendirinya, melainkan sejauh mana lingkungan keluarga, masyarakat, dan sekolah mampu mempengaruhi diri seseorang. Pembentukan karakter seorang anak sangat dipengaruhi oleh peran orang tua sebagai pendidik di dalam lingkungan keluarga serta peran pendidik di dalam lingkungan institusi pendidikan. Dibutuhkan metode yang tepat dalam membangun karakter siswa proses pendidikan karakter yang dilakukan melalui keteladanan, melalui penugasan dan pengasuhan, melalui pembiasaan, melalui program pelatihan, dan melalui partisipasi santri dalam 
berbagai jenis kegiatan, serta melalui penghargaan dan hukuman (Abdurrahman, 2016).

Mewujudkan karakter bangsa tentu saja harus ditopang dengan menggerakan semua komponen bangsa untuk peduli dan peka terhadap kondisi bangsa saat ini karena menciptakan kondisi suatu bangsa yang berkarakter harus diupayakan dan dilaksanakan secara bersama-sama dan saling sinergis antara pemerintah, masyarakat dan lembaga pendidikan. Pemerintah memberikan sebuah tempat atau wadah bahan aturan dalam menyusun kebijakan membangun karakter bangsa dan menjadi suri teladan bagi rakyatnya tidak hanya pada tataran regulasi namun sampai pada tahapan internalisasi. Lembaga pendidikan harus mampu membangun karakter peserta didik, mahasiswa, peserta diklat atau yang lainnya dengan tetap memiliki sikap idealisme yang tinggi berpegang teguh pada prinsip-prinsip kemanusiaan dalam rangka menciptakan masyarakat yang madani. Pendidikan karakter bertujuan untuk meningkatkan mutu proses dan hasil pendidikan yang mengarah pada pendidikan karakter dan akhlak mulia pembelajar secara utuh, terpadu, dan seimbang, sesuai dengan standar kompetensi lulusan pada setiap satuan pendidikan (Ramdhani, 2014). Capaian pembelajaran pada program studi kependidikan dari ranah sikap diantaranya sebagai berikut:

a. bertakwa kepada Tuhan Yang Maha Esa dan mampu menunjukkan sikap religius;

b. menjunjung tinggi nilai kemanusiaan dalam menjalankan tugas berdasarkan agama, moral, dan etika;

c. menginternalisasi nilai, norma, dan etika akademik;

d. berperan sebagai warga negara yang bangga dan cinta tanah air, memiliki nasionalisme serta rasa tanggungjawab pada negara dan bangsa;

e. menunjukkan sikap bertanggungjawab atas pekerjaan di bidang keahliannya secara mandiri. mempunyai ketulusan, komitmen, kesungguhan hati untuk mengembangkan sikap, nilai, dan kemampuan peserta didik. 


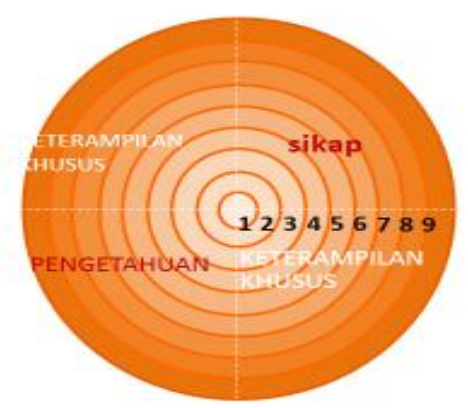

Diagram 1. Unsur Capaian Pembelajaran Standar Nasional Dikti

Untuk mewujudkan unsur capaian sikap setiap mata kuliah secara tidak langsung atau tersirat harus membangun nilai-nilai sikap mahasiswa. Mata kuliah yang disampaikan kepada mahasiswa memiliki tujuan, karakter dan nilai-nilai yang mampu menjunjung tinggi: nilai attitide, behaviours, enterpreunuer, responsibility sehingga mahasiswa memiliki karakter dan sifat yang baik yang melekat pada diri mahasiswa, misalnya pada mata kuliah kalkulus. Langkah pendidikan karakter meliputi perancangan, implementasi, evaluasi. dan tindak lanjut. Melalui pendidikan karekater pemahaman siswa tentang nilai meningkat, perilaku negatif menurun secara keseluruhan hal ini menunjukkan bahwa pendidikan karakter dibutuhkan untuk menghadapi sekaligus solusi terhadap masalah (Dodds, 2016).

\section{Capaian Pembelajaran Bidang Sikap Umum, Khusus dan Tata Nilai}

Untuk membangun karakter mahasiswa perlu dirumuskan capaian pembelajaran bidang sikap dan tata nilai salah satunya: Bertakwa kepada Tuhan Yang Maha Esa dan mampu menunjukkan sikap religius sebagai muslim, mukmin, dan muhsin; Menjunjung tinggi nilai-nilai etika akademik, yang meliputi kejujuran dan kebebasan akademik dan otonomi akademik. Sedangkan rumusan dan capaian bidang sikap umum dan tata nilai menjadi indikator dalam pengembangan dan implementasi setiap mata kuliah (Matematika, 2016). Mata kuliah yang diberikan kepada mahasiswa harus mampu mendorong dan mengarahkan mahasiswa kepada rumusan capaian sikap tersebut. Tidak sekedar pengetahuan yang dibangun aktif oleh dosen dan mahasiswa namun aktif membangun tata nilai yang baik.

Capaian pembelajaran bidang sikap khusus dan tata nilai diantaranya: memiliki akhlaqul karimah sesuai dengan nilai-nilai Islam dan matematika dalam kehidupan sehari-hari baik sebagai individu maupun kelompok. Capaian tersebut tidak hanya sekedar tulisan berupa simbol atau keinginan 
tanpa adanya upaya konkret namun lebih dari itu diperlukan upaya dalam mencapai capaian tersebut. Untuk membangun tata nilai tersebut seyogyanya pada rencana pembelajaran semester mencantumkan nilai afektif agar mahasiswa mengetahui dan menyadari bahwa assessment yang dilakukan dosen tidak hanya assessment kognitif namun disertai dengan assessment afektif. Assessment afektif menekankan pada sikap dan nilai-nilai religious, nasionalisme, kewarganegaraan, sikap dan tata nilai yang baik berada dalam lingkungan hidup bermasyarakat, berbangsa dan bernegara.

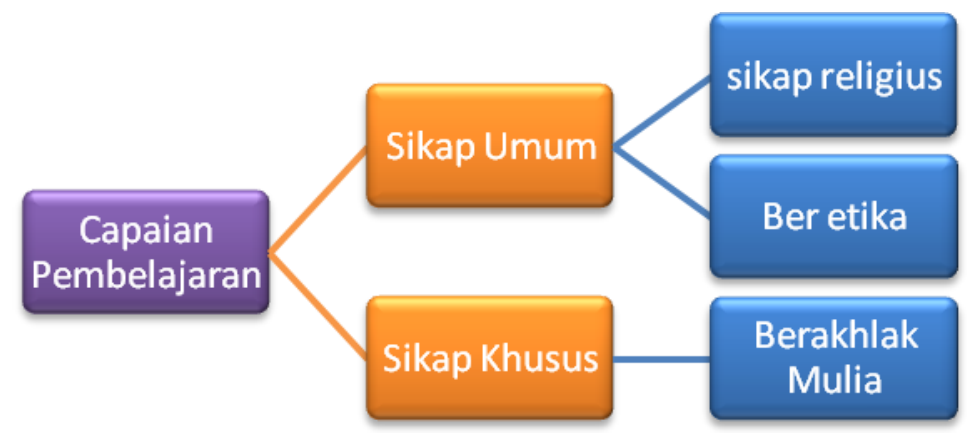

Diagram 2. Capaian Pembelajaran dan Tata Nilai

Berdasarkan diagram tersebut capaian pembelajaran dititik beratkan pada sikap khusus dan umum utuk membentuk karakter yang pribadi yang religious, beretika dan berakhlak mulia melalui penerapan capaian pembelajaran yang ditetapkan program studi.

\section{Langkah-langkah Internalisasi Karakter pada Mata Kuliah}

Upaya mewujudkan internalisasi karakter pada mata kuliah perlu didukung oleh semua civitas akademika khususnya dosen, mahasiswa dan unsur dekanat, mengingat terlaksananya pendidikan karakter harus satu tujuan berdasarkan visi dan misi. Nilai-nilai karakter yang diterapkan di perguruan tinggi, khususnya di LPTK melalui tiga jalur, yaitu pembelajaran, manajemen perguruan tinggi, dan kegiatan kemahasiswaan. Dan hanya memilih nilai- nilai inti (core volues) yakni jujur, cerdas, peduli dan tangguh menjadi dasar implementasi nilai-nilai karakter. Penyelenggaraan pendidikan karakter di perguruan tinggi (LPTK) dilakukan secara terpadu (Hasanah, 2014). Adapun langkah-langkah tersebut disajikan dalam tabel sebagai berikut: 
Tabel 1. Tahapan Pengembangan Pendidikan Karakter

\begin{tabular}{|c|c|c|}
\hline Jenis & Tahap Kegiatan & $\begin{array}{c}\text { Tahap } \\
\text { Pelaksanaan }\end{array}$ \\
\hline \multirow[t]{4}{*}{ Perancangan } & $\begin{array}{l}\text { Mengidentifikasi jenis-jenis } \\
\text { kegiatan di prodi yang dapat } \\
\text { merealisasikan pendidikan } \\
\text { karakter yang perlu dikuasai, } \\
\text { dan direalisasikan peserta } \\
\text { didik dalam kehidupan } \\
\text { sehari-hari }\end{array}$ & $\begin{array}{l}\text { Melalui rapat } \\
\text { dosen dalam } \\
\text { menysuun capaian } \\
\text { pembelajaran } \\
\text { untuk pelaksanaan } \\
\text { visi misi prodi }\end{array}$ \\
\hline & $\begin{array}{l}\text { Menentukan capaian } \\
\text { pembelajaran bidang sikap } \\
\text { umum, khusus dan tata nilai }\end{array}$ & $\begin{array}{lr}\text { Melalui } & \text { rapat } \\
\text { dosen membahas } \\
\text { silabus mata kuliah }\end{array}$ \\
\hline & $\begin{array}{l}\text { Mengidentifikasi karakteristik } \\
\text { mata kuliah ditinjau dari } \\
\text { capaian pembelajaran bidang } \\
\text { sikap umum }\end{array}$ & $\begin{array}{l}\text { Analisa spesifikasi } \\
\text { mata kuliah dalam } \\
\text { aspek afektif }\end{array}$ \\
\hline & $\begin{array}{l}\text { Mengembangkan silabus dan } \\
\text { rencana pelaksanaan semester } \\
\text { (RPS) dari aspek penilaian } \\
\text { sikap }\end{array}$ & $\begin{array}{lr}\text { Membuat } & \text { form } \\
\text { silabus } & \text { memuat } \\
\text { penguatan } & \text { karakter } \\
\text { dan } & \text { melalui } \\
\text { kegiatan } & \text { rapat } \\
\text { menyusun } & \text { nilai- } \\
\text { nilai karakter yang } & \\
\text { akan dicapai } & \end{array}$ \\
\hline Implementasi & 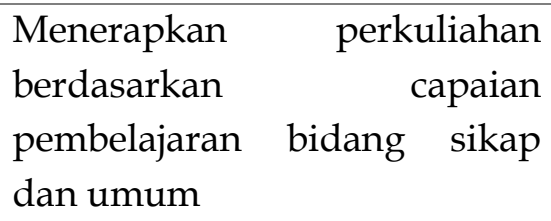 & $\begin{array}{l}\text { Mengisi form } \\
\text { capaian } \\
\text { pembelajaran pada } \\
\text { akhir perkuliahan }\end{array}$ \\
\hline Evaluasi & $\begin{array}{ll}\text { Melakukan evaluasi } & \text { melalui } \\
\text { prosentase } & \text { capaian } \\
\text { pembelajaran } & \end{array}$ & $\begin{array}{l}\text { Mengevaluasi } \\
\text { target capaian }\end{array}$ \\
\hline Tindak lanjut & $\begin{array}{l}\text { Refleksi dan analisis hambatan } \\
\text { dan tindak lanjut capaian } \\
\text { pembelajaran }\end{array}$ & $\begin{array}{l}\text { Melakukan refleksi } \\
\text { bersama dosen, } \\
\text { mahasiswa dan } \\
\text { stake holder. }\end{array}$ \\
\hline
\end{tabular}




\section{Internalisasi Mata Kuliah untuk Membangun Karakter}

Kalkulus merupakan salah satu mata kuliah prodi pendidikan matematika beberapa pendapat menyebut bahwa kalkulus adalah the body of mathematics. Mata kuliah kalkulus terdiri dari kalkulus diferensial, kalkulus integral, kalkulus peubah banyak dan lain sebagainya masing-masing memiliki tujuan khusus dan tujuan umum serta tujuan sikap yang diharapkan baik dari segi konten atau isi materi kuliah maupun dari karakter yang tersirat secara tidak langsung. Mahasiswa mampu mengembangkan kemampuan berkomunikasi, berkolaborasi dan sikap bertanggung jawab dan kejujuran dalam proses perkuliahan dan penyelesaian tugas-tugas: memecahkan masalah yang berkaitan dengan kalkulus, memahami dan mengerti kalkulus dengan baik dan dapat diaplikasikan pada bidang lainnya.

Misalnya materi grafik fungsi mengeksplorasi tentang fungsi yang kontinu dan tak kontinu. Penilaian sikap dilakukan sepanjang semester (akumulatif), mencakup: kesungguhan melaksanakan proses perkuliahan secara aktif, kedisplinan menghadiri perkuliahan, ketepatan waktu hadir. Penilaian kognitif salah satunya adalah ketepatan dalam menyelesaikan masalah berkaitan dengan grafik fungsi dan kekontinuan fungsi. Karakter yang dibangun pada materi grafik fungsi adalah kejujuran, ketelitian, kesungguhan mahasiswa yang tidak memahami bagaimana cara mengkontruksi grafik fungsi akan kesulitan dalam menggambar grafik mahasiswa harus mengetahui domain dan range fungsi tersebut. Tentukan domain, kodomain, range dan sketsa grafik fungsi $f(x)=\sqrt{x+1}$.

Nilai karakter yang dibangun dari masalah tersebut adalah nilai ketelitian, kreatif, mandiri dan kerja keras. Nilai tersebut dapat diamati atau diketahui berdasarkan jawaban mahasiswa saat mengerjakan dan hasil yang ia tulis pada lembar jawaban. Mahasiswa yang mencontek akan ketahuan dikarenakan tanpa memahami soal dengan baik ia sulit mengerjakan bahkan mengerjakan pun akan kesulitan. Mandiri dan kreatif secara tidak langsung terbangun dari kegiatan mahasiswa menggambar grafik, mahasiswa yang kreatif tentunya menggunakan kertas milimiter blok, menggunakan penggaris atau menggambar terlebih dahulu berbantuan software matematika. Masalah tersebut harus diselesaikan oleh masing-masing atau mandiri tidak mungkin dikerjakan oleh orang lain. Hasil penilaian diumumkan kepada mahasiswa setelah satu tahap pembelajaran sesuai dengan rencana pembelajaran sebagai bentuk tanggung jawab dosen dalam membentuk karakter mahasiswa yang 
jujur, transparan dan bertanggung jawab. Salah satunya terdapat dalam materi Integral. Karakteristik siswa yang dapat dibangun dari materi ini diantaranya adalah:

\section{Rasa Ingin Tahu dan Kreatif}

Dalam materi integral, banyak sekali bentuk permasalahan yang berbeda. Contoh halnya integral trigonometri, integral pasial dan lain sebagainya. Tentu pengerjaannya pun tidak semua sama. Maka disinilah secara tidak langsung siswa dituntut untuk memiliki rasa ingin tahu dan kreatifitas dalam mengerjakan berbagai macam bentuk soal yang berbeda tanpa keluar dari kaidah keilmuan.

\section{Sistematis}

Terdapat tahap-tahap pengerjaan soal integral. Hampir semua jenis soal integral membutuhkan pemisalan fungsi, menentukan pola turunan dan integral suatu fungsi, dan melihat apakah ada syarat tertentu sebelum mengerjakannya. Sistematis disini terdapat susunan dan urutan dalam pengerjaannya.

\section{Teliti}

Proses integral tidaklah rumit, hanya saja perlu hati-hati dan teliti saat memisalkan fungsi, ada syaratnya kah, begitupun dalam menentukan batas, apalagi jika melibatkan batas-batas negatif dan masih banyak lagi karakteristik yang dapat ditumbuhkan pada jiwa siswa melalui pembelajaran matematika, salah satunya melalui materi integral ini. Perlu disampaikan juga banyak sekali kegunaan mempelajari integral yang dapat diaplikasikan dalam bidang teknik, bidang ekonomi, bidang fisika, teknologi, kedokteran dan lain sebagainya agar siswa tidak merasa materi ini tidak berpengaruh pada kehidupan mereka sehingga membuat semangat belajar mereka berkurang dan kurang berkembangnya tiga atau lebih karakteristik yang seharusnya dibangun dari mempelajari materi ini. Berikut disajikan hasil angket mahasiswa yang disebar kepada 37 mahasiswa perihal pendidikan karakter terdiri dari lima pernyataan. 
Tabel 2. Hasil Angket Sikap Mahasiswa terhadap Nilai-Nilai Karakter

\begin{tabular}{llll}
\hline No & \multicolumn{1}{c}{ Pernyataan } & Ya (\%) & Tidak (\%) \\
\hline 1 & $\begin{array}{l}\text { Setiap mata kuliah pada prodi pendidikan matematika } \\
\text { membangun karakter mahasiswa }\end{array}$ & 64.86 & 24.32 \\
\hline 2 & $\begin{array}{l}\text { Penilaian dosen melibatkan aspek afektif untuk } \\
\text { membangun karakter }\end{array}$ & 59.46 & 40.54 \\
\hline 3 & Mahasiswa membutuhkan suri tauladan dari dosen & 67.57 & 32.43 \\
\hline 4 & $\begin{array}{l}\text { Sikap atau karakter dosen mempengaruhi karakter } \\
\text { mahasiswa }\end{array}$ & 62.16 & 27.03 \\
\hline 5 & Karakter mahasiswa pada saat ini perlu ditingkatkan & 67.57 & 32.43 \\
\hline
\end{tabular}

Berdasarkan tabel 2, empat pernyataan sikap mahasiswa terhadap nilainilai karakter memiliki prosentase di atas $60 \%$. Hal ini berarti mahasiswa memberikan respon positif terhadap peran dosen atau prodi dalam membangun karakter mahasiswa. Meskipun mahasiswa tetap saja membutukan suri tauladan dari dosen dalam membangun karakter mahasiswa.

\section{SIMPULAN}

Untuk membentuk karakter mahasiswa, perlu dituangkan kedalam capaian pembelajaran yang ditetapkan oleh program studi pendidikan matematika. Setiap mata kuliah memiliki nilai-nilai karakter yang dibentuk dari setiap substansi materi dan tiap mata kuliah memiliki kekhasan dalam membangun karakter tersebut. Setiap mata kuliah memiliki perbedaan terhadap nilai yang dibangun misalnya rumpun statistika berbeda dengan analisis atau rumpun geometri. Nilai-nilai tiap mata kulaih dapat membangun karakter mahasiswa meliputi sikap sungguh-sungguh, teliti, jujur, kerja keras, tekun dan yang lainnya. Mahasiswa memerlukan pendidikan karakter dikarenakan meskipun sebagai mahasiswa tetap saja membutuhkan figur teladan dan muatan karakter dalam setiap mata kuliah.

\section{DAFTAR PUSTAKA}

Abdurrahman, N. H. (2016). Character education in islamic boarding schoolbased SMA Amanah. Jurnal Pendidikan Islam, 2(2), 287-305. Retrieved from http://journal.uinsgd.ac.id/index.php/jpi/article/view/791/683

Dodds, D. M. (2016). The effects of character education on social-emotional behavior. Masters of Arts in Education Action Research Papers Education. 
Retrieved from https://sophia.stkate.edu/maed/137

Gray, T. (2009). Character education in schools. ESSAI, 7, 56-61. Retrieved from http:/ / dc.cod.edu/essai/vol7/iss1/21

Hasanah. (2013). Implementasi nilai-nilai karakter inti di perguruan tinggi. Jurnal Pendidikan Karakter, (2), 186-195. Retrieved from https://journal.uny.ac.id/index.php/jpka/article/view/1439/1227

Hasanah, A. (2014). Kerangka konsep pendidikan karakter bangsa dalam perspektif islam. Jurnal Penjaminan Mutu, 1(1), 1-30. Retrieved from http://digilib.uinsgd.ac.id/4121/1/Aan_Hasanah_Jurnal_Kerangka_K onsep_Pendidikan_Karakter_Bangsa.pdf

Mahmudi, A. (2011). Developing students' character through mathematics teaching and learning. In Building the Nation Character through Humanistic Mathematics Education. Yogyakarta: Department of Mathematics Education, UNY. Retrieved from https:/ / eprints.uny.ac.id/1366/1/P - 49.pdf

Matematika, T. P. (2016). Kurikulum merujuk KKNI. Bandung: Prodi Pendidikan Matematika UIN SGD Bandung.

McDonnell, S. (2008). America's crisis of character-and what to do about it. education week, 28(7), 25. Retrieved from https:// www.edweek.org/ ew/articles/2008/10/08/07mcdonnell.h28. html

Ramdhani, M. A. (2014). Lingkungan pendidikan dalam implementasi pendidikan karakter. Jurnal Pendidikan UNIGA, 8(1), 28-37. Retrieved from https:/ /journal.uniga.ac.id/index.php/JP/article/view/69/70

Republik Indonesia. (2017). Peraturan presiden republik indonesia nomor 87 Tahun 2017 tentang penguatan pendidikan karakter. Jakarta: Sekretariat Negara. Retrieved from http://setkab.go.id/wpcontent/uploads/2017/09/Perpres_Nomor_87_Tahun_2017.pdf 